\title{
The Performance of Pakistan's Agricultural Markets in the Green Revolution Perspective
}

\author{
FAIZ MOHAMMAD*
}

\section{INTRODUCTION}

The performance of the existing agricultural marketing system in developing countries has been a subject of considerable debate in the past many years. ${ }^{1}$ One of the many issues of this debate concerns the ability of the traditional marketing system to adopt new technology and to accommodate any increase in agricultural productivity without leaving "harmful" effects on the consumer or on the farmer. Other things being equal, any agricultural marketing system which enables the farmer to benefit from the adoption of a new farm technology, at least as much as other market participants would do, may be regarded as having performed "well" [14] .

Against this background the present paper attempts to study changes in the prices received by the farmer, resulting from the interaction of the Green Revolution in the Punjab and Sind in the Sixties with agricultural marketing in the country.

Although the critics of the Green Revolution are yet to be convinced that this "revolution" was as "green" as is popularly believed, one certainly finds the increases in per acre yields of wheat and (coarse) rice in the late Sixties unprecedented in the history of Pakistan's agriculture. ${ }^{3}$ Due to the introduction of High Yielding Varieties, like Mexi-Pak wheat and IRRI rice, yield per acre of wheat increased from $330 \mathrm{~kg}$ in $1966-67$ to $435 \mathrm{~kg}$ in $1967-68$ (i.e. $32 \%$ ) and to $473 \mathrm{~kg}$ in $1969-70$ (i.e. by $43 \%$ compared to the $1966-67$ figure). The yield per acre of rice (all varieties), on the other hand, increased from $393 \mathrm{~kg}$ in $1966-67$ to $439 \mathrm{~kg}$ in $1967-68$ and to $533 \mathrm{~kg}$

*Research Economist, Pakistan Institute of Development Economics, Islamabad (Pakistan).

${ }^{1}$ See [9] for further details of this debate.

${ }^{2}$ Also see Harris [3], Jones [4;5] and Lele [7] for other methods of evaluating the performance of these markets. menon.

${ }^{3}$ See Griffen [2] and Khan [6] for a critical evaluation of the Green Revolution pheno- 
in 1968-69, registering an increase of 36 percent for the 1966-67-1968-69 period $[9$, p. 155$] .^{4}$

Both total production and marketable surplus of these two commodities also increased significantly during this period [9]. The increase in marketable surplus naturally affected such marketing conditions as transportation and storage of commodities, and, thereby, also affected the price received by the farmer. Moreover, in Pakistan where there is more than one level of agricultural marketing and where the farmer's participation in a particular market level depends on, among other things, the amount of the marketable surplus he holds, an increase in farm productivity must alter the environment within which an exchange between the trader and the farmer takes place. The fundamental premiss of this paper is that during the Green Revolution period, as the farmer had more marketable surplus in his hand, he made greater efforts to secure his desired price. This strengthened his bargaining position and allowed him a better price for his produce.

In this paper, first a conceptual framework is developed to show the effect of the Green Revolution phenomenon on different levels of agricultural markets, and then, through empirical tests, the behaviour of the prices of wheat and rice (coarse) in the Green Revolution period is compared with that in the earlier periods. The final section presents the main conclusions of the paper.

\section{MARKET PRICES AND GREEN REVOLUTION : A CONCEPTUAL FRAMEWORK}

In Pakistan's private sector, the three types of the better-recognized agricultural markets are: village markets, primary wholesale markets and terminal markets. ${ }^{5}$ Village markets are located close to farmgate and in them village traders buy marketable surplus directly from the farmer. Primary wholesale markets, are generally located in district towns or in major sub-divisional towns, such as Jaranwala in Faisalabad district. Here both farmers and village traders bring their produce, which is usually disposed of through the commission agent known as 'arhti'. The major trader, known as pukka arhti, who also acts as a local wholesaler and an agent of traders in other markets, buys most of the quantities brought to these markets. Terminal markets are those to which all the marketable surplus not absorbed by

${ }^{4}$ See Mohammad [9, p. 155] for details of these figures. Since figures relating to IRRI rice alone were not available for the year 1966-67, data for 'all varieties' were used for calculating the increase in rice yields per acre over the given period.

${ }^{5}$ For a detailed description of these markets, see [9]. Private agricultural markets used to handle almost all the marketable surplus of major farm outputs, except rice, in the Fifties and Sixties. However, owing to heavy procurement of wheat by the government in recent years their role has been somewhat curtailed. Nevertheless they still play a considerable role in handling farm products at various stages. village or primary wholesale markets is ultimately brought. Karachi, Quetta and Rawalpindi are some of the examples of this type of markets. Only pukka arhtis conduct business in them.

To study the effect of the Green Revolution on agricultural prices, we have, in Figures I, II and III, shown the behaviour of supply and demand for a commodity in the three types of markets stated above. In each of the three cases, the supply and demand curves have all the properties of ordinary supply and demand functions except that here they relate to a semi-final product for which the demand is not from the final consumer but from market intermediaries who purchase a commodity for resale purposes.

In drawing these curves, we have assumed that the trader adds some margin to his purchase price to cover handling costs when a product is moved from one market to another. In this way, PC (the price received by the trader who sells a commodity to the highest link in this marketing channel) is higher than PT (the price received by a seller in the primary wholesale market) which in turn is higher than PF (the price received by the farmer by selling his produce in the village market). Formally

$$
P F<[P T=(P F+M T+H C T)]<[P C=(P T+M C+H C C)] \quad \ldots
$$

where $M T$ is the market margin of the trader who sells a commodity in a primary wholesale market, and $H C T$ is his handling cost. Similarly $M C$ is the market margin of the trader who sells in the marketing level ' $C$ ' and $H C C$ is his cost of bringing supplies to this point.

Under these simplified conditions, one may expect that the increase in marketable surplus due to the Green Revolution phenomenon would shift the supply curve $(S S)$ to $S ́ S$ in each market and depress the equilibrium prices, $P F, P T$, and $P C$ to $P F$, and $\dot{P} T$, and $\dot{P} C$. This may happen because traders in different markets have limited capacity and can not handle supplies beyond a certain level, unless price is scaled down by the seller. However, if we take into consideration the factors which could shift the demand curve rightward (i.e. to $D^{\prime}{ }^{\prime}$ ) in the cases of all the markets and the supply curve leftward (i.e. to $S S$ ), particularly in the cases of lower-level markets, then despite an increase in the overall supply of a commodity, prices in the lower level markets could go up instead of going down. In the case of Pakistan's agricultural markets this latter outcome seems more likely for the following reasons.

1. The number of traders, particularly at the village and the primary wholesale markets' levels, increased significantly during the Green Revolution period. Based on 13 major markets in Pakistan it is estimated that on average the number of commission agents (arhtis) 


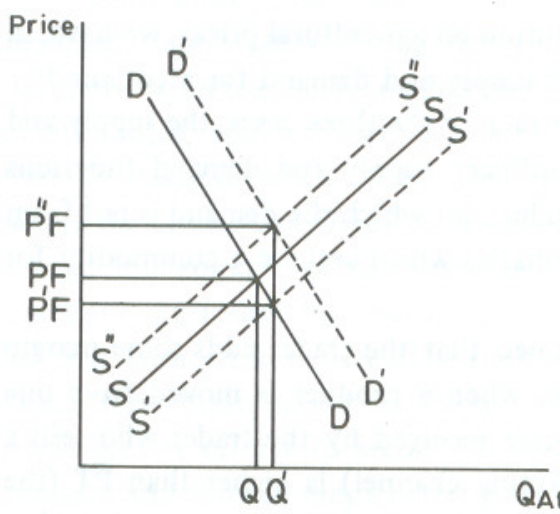

Quantity

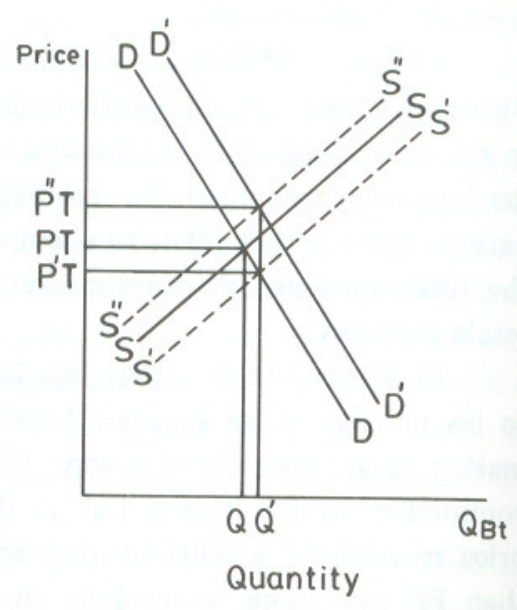

Fig. II. Interaction of Supply and Demand in a Primary Wholesale Market.

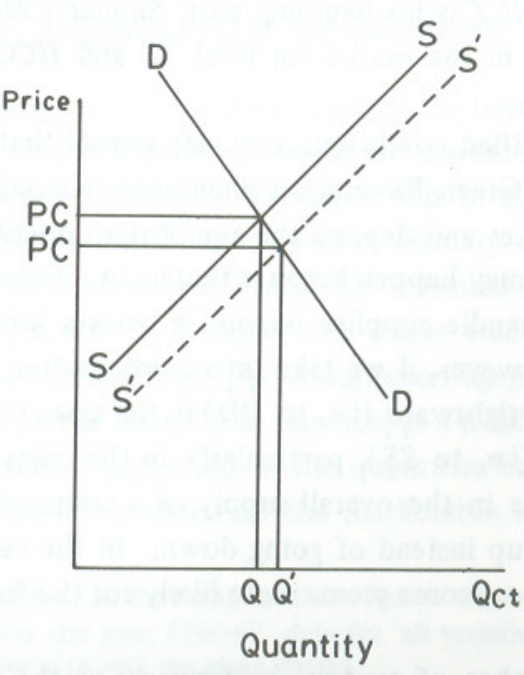

Fig. III. Interaction of Supply and Demand in "Other Markets" in a market increased from 98 in 1965-66 to 133 in 1967-68, and to 154 in 1968-69 (an increase of 57 percent over the number in 1965-66) [9]. This might have happened for two reasons: (i) new volume of marketable surplus was bound to expand trade at each level and, thus, attract more traders into the business; (ii) because of the increase in farm productivity and the introduction of farm mechanization during this period, not all family labour was required to work on farms, particularly on those farms which produced only a given amount of foodstuff. ${ }^{6}$ Some labour, so released, was expected to join alternative economic activities, trading in farm products and in cattle being the most important among them. An increase in the number of traders is expected to increase the number of competitors bidding for farm products, which in terms of Figures I to III implies a shift in the demand curve to $D^{\prime} D$ ?

2. With large quantity of marketable surplus the farmer is generally observed to show a higher degree of entrepreneurship and "selectiveness" in disposing of his produce. ${ }^{8}$ This is particularly true in countries like Pakistan where, owing to poor transportation facilities and imperfect information, the farmer with small amount of marketable surplus is more likely to sell his produce to the nearest marketing point rather than to search for a "better" price. With large quantities in hand, he is expected to explore marketing prospects at all levels of markets before selling his produce. In this situation, if the local trader does not offer him his desired price, he could move his supplies to an upper level market. The supply curve in the lower level markets could therefore move to $\stackrel{S}{S} S^{\prime}$ rather to $S S S$ if the farmer decides to part

${ }^{6}$ Other things being equal, an increase in productivity of land $(\mathrm{N})$ would result in a greater use of land and a lesser use of labour (L) at a given level of output. This happens because a equilibrium point, marginal product of land (MPN) divided by rental value of land (PN) must equal marginal product of labour (MPL) divided by its price (PL), and any increase in MPN must tend to increase the use of $N$ if the equality is to be maintained. See Bilas [1] for a detailed analysis of this point.

Such a shift in the demand curve is not shown to have taken place in terminal markets, firstly because we were told by traders in all the markets we visited in connection with this project that only at the lower marketing levels the number of market functionaries in with this pro so much at the terminal market level. This is understandable because at the lower level much below about a change in the maketing envir. level the demand change in the marketing environment would also indicate that only at the lowe 8 it is pernd curve should shift to DD. It is perhaps for this reason that the "large" farmer is observed to sell more of his market-
able surplus in the upper level markets. See [9] for evidence. 
from the traditional local buyer of his produce. In case the local trader decides to offer him better terms, this would mean a shift in the demand curve in these markets to $D^{\prime} D^{\prime}$. It is also important to mention here that no matter whether the move by the farmer to take his supplies to an upper level market is real or potential, the local trader is expected to offer him better price as only in this way he can retain his share of the business. This he can do either by cutting down his own margin or by finding efficient ways of handling his business. In this process the farmer gets better price and the performance of the marketing system is improved.

In view of the above-stated factors, the prices established in different markets are likely to be as follows:

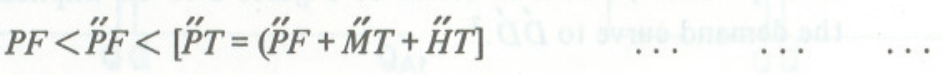

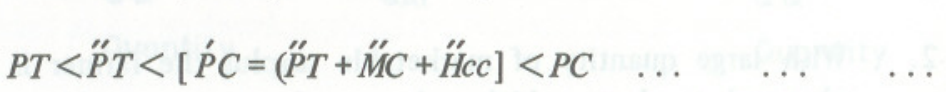

$$
\begin{aligned}
& \begin{array}{llllllll}
\| M C<M C & \ldots & \ldots & \ldots & \ldots & \ldots & \ldots
\end{array}
\end{aligned}
$$

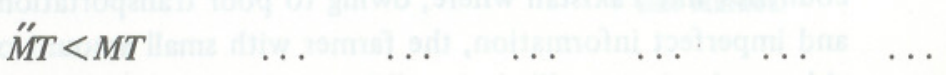

One of the corollaries of the above model is that with a large volume of marketable surplus, not only over space but also over time, the farmer would allocate his supplies in such a manner that his net expected price is improved.

\section{Main Hypotheses to be Tested}

Based on the preceding conceptual framework, the following main hypotheses are to be tested in this paper.

1. The average net price, received by the farmer, of the two main commodities (wheat and rice), ${ }^{9}$ increased significantly during the Green Revolution period.

2. The marketing margin of the trader, which partly determines the net share of the market price received by the farmer, decreased during the Green Revolution.

3. As the Green Revolution also improved the farmer's understanding of intertemporal price formation process, storage margin of the stock-keeper, who stored agricultural commodities for offseason sales, went down during the Green Revolution period.

\footnotetext{
${ }^{9}$ Hereafter the term rice refers to the coarse rice variety unless stated otherwise.
}

4. Compared with the farm prices of wheat and rice in private markets, there were no significant changes in 'floor prices' announced by the Government during the Green Revolution period.

The purpose of this last point is to see if the improvement in farm prices was the result of forces inherently working within the private marketing system or of any artificial factor.

In the following section we test these hypotheses one by one.

\section{METHODS OF TESTING HYPOTHESES AND EMPIRICAL RESULTS}

\section{Comparison of Prices Received by the Farmer During and Before the}

\section{Green Revolution Period}

In an ideal situation, the first hypothesis stated above could be tested by comparing the actual prices received by the farmer, before and during the Green Revolution period. Unfortunately however, the necessary data are not available in Pakistan. We, therefore, have to rely on secondary data on monthly average wholesale prices in certain selected markets as reported in Pakistan [11]. ${ }^{10}$ Subtracting farm-tomarket transportation and handling costs from those prices, we obtained price data which might be the closest to the prices actually received by the farmer. Using these data (in nominal and real forms) from January 1955 to June 1971 for wheat and from January 1960 to June 1971 for (clean) rice, we estimated the following equations. ${ }^{11}$

$$
\begin{array}{llll}
N P i_{t}=b_{0}+b_{1} T+b_{2} D+e & \ldots & \ldots & \ldots \\
R P i_{t}=c_{0}+c_{1} T+c_{2} D+e^{\prime} & \ldots & \ldots & \ldots
\end{array}
$$

where $N P i_{t}=$ Average monthly wholesale prices (nominal) of an $i$ th commodity in a market at time $t$, minus farm-to-market transportation and handling costs;

$R P i_{t}=N P i_{t} /$ Wholesale price index (WPI) of the relevent month;

${ }^{10}$ Our choice of a market to be studied here was mainly based on the availability of continuous time-series of price data for a market. On this criterion only 13 markets could be selected, the list of which is given in Table 1 .

${ }^{11}$ The data for the years after 1971 were ignored because the Pakistani Rupee was devalued in January 1972, changing drastically the price structures of domestic and imported goods. Inclusion of these data would have made it difficult to separate the effect of one variable from the others. Also for rice we could not use paddy prices which were parhaps theoretically
mates more relevent here as such-time series data were not available. 

June 1971 for rice;

= A Dummy variable, which is equal to one for the period from January 1967 to June 1971 (the Green Revolution period) and to zero otherwise; and

$b_{0}, b_{1}, b_{2}$ and $c_{0}, c_{1}, c_{2}$ are the coefficients to be estimated. $b_{1}$ is expected to be positive as prices generally rise over time, but $c_{1}$ may be positive or negative depending on how prices of commodities under study behaved in comparison with WPI.

dicating that the prices of wheat and rice went up significantly from their trend values during the Green Revolution period.

\section{Empirical Results}

The OLS estimates of equations (6) and (7) for wheat are presented in Table 1 while those for (coarse) rices are given in Table 2. The results based on nominal prices strongly support our hypothesis. The coefficient $b_{2}$ is significant at the 5-percent level or less for all the markets and has the positive sign, except for the Gujranwala rice market. Gujranwala rice prices have been generally under government control, and hence appear to have responded little to changes in the private market situation. These estimates show that on average nominal prices received by the farmer during the Green Revolution period went up by the value of the coefficient $b_{2}$ which ranges between 1.76 and 4.00 for wheat and 1.61 and 22.00 for rice for different markets.

The estimates based on real prices also support our hypothesis, though not very strongly in the case of wheat. The coefficient $c_{2}$ for rice is significant at the 1-percent level for all the markets except Gujranwala. For wheat it is significant at the 5-percent level only in the cases of Faisalabad, Gujranwala, Okara, Sialkot and Sahiwal markets. For some other markets, it is significant at the 10-percent level or more. In the cases of Karachi and Lahore markets the sign of this coefficient is negative, indicating that the real prices of wheat in these markets might have declined during the Green Revolution period. This latter is not unexpected as we predicted an increase in farm prices only at the lower level market. Karachi and Lahore are more like terminal markets.

\section{Marketing Margins during the Green Revolution Period}

Calculation of margins of traders at different stages of marketing requires selling and buying prices at each stage. Unfortunately, no historical data on this aspect of prices are available in Pakistan. The only historical data available were
Table 1

Relationship between Prices of Wheat, the Time Variable and a Dummy Variable, for Selected Agricultural Markets in Pakistan January 1955 to June 1971 *

\begin{tabular}{|c|c|c|c|c|c|c|c|c|}
\hline \multirow[b]{2}{*}{ Markets } & \multicolumn{4}{|c|}{ Equation 6 using nominal prices } & \multicolumn{4}{|c|}{ Equation 7 using real prices } \\
\hline & $b_{0}$ & $b_{1}$ & $b_{2}$ & $F$ & $c_{0}$ & $c_{1}$ & $c_{2}$ & $F$ \\
\hline Faisalabad & 15.33 & $\begin{array}{r}0.035 \\
(7.68)\end{array}$ & $\begin{array}{c}2.83 \\
(3.61)\end{array}$ & 147.34 & 13.29 & $\begin{array}{c}0.018 \\
(2.71)\end{array}$ & $\begin{array}{r}0.605 \\
(2.05)\end{array}$ & 23.75 \\
\hline Gujranwala & 15.92 & $\begin{array}{c}0.032 \\
(6.25)\end{array}$ & $\begin{array}{c}2.66 \\
(3.25)\end{array}$ & 151.49 & 13.78 & $\begin{array}{c}0.017 \\
(2.25)\end{array}$ & $\begin{array}{c}0.638 \\
(1.985)\end{array}$ & 21.39 \\
\hline Hyderabad & 15.37 & $\begin{array}{c}0.038 \\
(7.72)\end{array}$ & $\begin{array}{c}2.80 \\
(4.20)\end{array}$ & 181.65 & 13.17 & $\begin{array}{l}0.019 \\
(2.11)\end{array}$ & $\begin{array}{c}0.546 \\
(1.875)\end{array}$ & 20.87 \\
\hline Karachi & 16.55 & $\begin{array}{r}0.043 \\
(10.38)\end{array}$ & $\begin{array}{c}1.76 \\
(2.19)\end{array}$ & 240.39 & 14.02 & $\begin{array}{l}0.029 \\
(1.98)\end{array}$ & $\begin{array}{c}-0.296 \\
(0.863)\end{array}$ & 20.03 \\
\hline Lahore & 15.59 & $\begin{array}{l}0.038 \\
(7.37)\end{array}$ & $\begin{array}{c}2.08 \\
(4.84)\end{array}$ & 217.30 & 13.83 & $\begin{array}{c}0.021 \\
(3.37)\end{array}$ & $\begin{array}{c}-0.372 \\
(1.39)\end{array}$ & 20.66 \\
\hline Multan & 15.05 & $\begin{array}{c}0.039 \\
(6.61)\end{array}$ & $\begin{array}{c}2.81 \\
(3.40)\end{array}$ & 164.4 & 13.07 & $\begin{array}{c}0.024 \\
(2.74)\end{array}$ & $\begin{array}{c}0.596 \\
(1.98)\end{array}$ & 24.12 \\
\hline Okara & 14.97 & $\begin{array}{l}0.039 \\
(6.98)\end{array}$ & $\begin{array}{c}2.91 \\
(3.90)\end{array}$ & 137.99 & 12.81 & $\begin{array}{l}0.023 \\
(2.73)\end{array}$ & $\begin{array}{l}0.937 \\
(2.57)\end{array}$ & 25.98 \\
\hline Peshawar & 15.92 & $\begin{array}{l}0.028 \\
(4.74)\end{array}$ & $\begin{array}{c}2.42 \\
(3.32)\end{array}$ & 83.17 & 13.77 & $\begin{array}{c}0.018 \\
(1.91)\end{array}$ & $\begin{array}{c}0.565 \\
(1.735)\end{array}$ & 18.23 \\
\hline Rawalpindi & 15.65 & $\begin{array}{c}0.031 \\
(5.64)\end{array}$ & $\begin{array}{c}2.11 \\
(2.97)\end{array}$ & 103.25 & 14.06 & $\begin{array}{r}0.017 \\
(1.54)\end{array}$ & $\begin{array}{c}-0.215 \\
(0.215)\end{array}$ & 18.74 \\
\hline Sahiwal & 15.17 & $\begin{array}{c}0.044 \\
(7.26)\end{array}$ & $\begin{array}{c}2.64 \\
(2.89)\end{array}$ & 138.99 & 12.95 & $\begin{array}{l}0.026 \\
(2.85)\end{array}$ & $\begin{array}{l}0.896 \\
(2.32)\end{array}$ & 26.01 \\
\hline Sargodha & 14.39 & $\begin{array}{r}0.034 \\
(5.88)\end{array}$ & $\begin{array}{c}3.17 \\
(3.81)\end{array}$ & 101.77 & 13.03 & $\begin{array}{c}0.021 \\
(2.39)\end{array}$ & $\begin{array}{c}0.786 \\
(1.97)\end{array}$ & 24.65 \\
\hline Sialkot & 15.39 & $\begin{array}{c}0.037 \\
(6.15)\end{array}$ & $\begin{array}{c}2.86 \\
(2.97)\end{array}$ & 121.59 & 13.08 & $\begin{array}{l}0.022 \\
(2.05)\end{array}$ & $\begin{array}{l}0.695 \\
(1.92)\end{array}$ & 22.14 \\
\hline
\end{tabular}

Sources: Computations are based on price data from [11]. For other data, see Mohammad [9, pp. 267-68].

*Prices here refer to average monthly wholesale prices received by the farmer. Figures in brackets are $t$-values. 
Table 2

Relationship between Prices of (Coarse) Rice, the Time Variable, and a Dummy Variable for Selected Agricultural Markets in Pakistan, January 1960 to June 1971 *

\begin{tabular}{|c|c|c|c|c|c|c|c|c|}
\hline \multirow{2}{*}{ Markets } & \multicolumn{4}{|c|}{ Equation 6 using nominal prices } & \multicolumn{4}{|c|}{ Equation 7 using real prices } \\
\hline & $b_{0}$ & $b_{1}$ & $b_{2}$ & $F$ & $c_{0}$ & $c_{1}$ & $c_{2}$ & $F$ \\
\hline Faisalabad & 24.58 & $\begin{array}{r}-0.083 \\
(4.15)\end{array}$ & $\begin{array}{c}12.39 \\
(8.47)\end{array}$ & 54.02 & 21.86 & $\begin{array}{r}-0.081 \\
(6.09)\end{array}$ & $\begin{array}{c}6.59 \\
(6.26)\end{array}$ & 21.57 \\
\hline Gujranwala & 15.56 & $\begin{array}{c}0.04 \\
(2.95)\end{array}$ & $\begin{array}{c}1.61 \\
(1.59)\end{array}$ & 14.74 & 14.54 & $\begin{array}{l}0.048 \\
(.449)\end{array}$ & $\begin{array}{c}-0.539 \\
(0.688)\end{array}$ & 0.294 \\
\hline Hyderabad & 23.59 & $\begin{array}{c}-0.087 \\
(3.25)\end{array}$ & $\begin{array}{c}9.876 \\
(5.03)\end{array}$ & 37.76 & 21.01 & $\begin{array}{c}-0.092 \\
(4.75)\end{array}$ & $\begin{array}{r}5.197 \\
(3.63)\end{array}$ & 16.46 \\
\hline Karachi & 36.25 & $\begin{array}{r}-0.069 \\
(5.53)\end{array}$ & $\begin{array}{c}4.01 \\
(2.75)\end{array}$ & 39.46 & 32.56 & $\begin{array}{c}-0.066 \\
(5.28)\end{array}$ & $\begin{array}{r}3.747 \\
(2.39)\end{array}$ & 17.39 \\
\hline Lahore & 24.08 & $\begin{array}{r}-0.077 \\
(4.86)\end{array}$ & $\begin{array}{c}11.078 \\
(9.50)\end{array}$ & 65.41 & 21.48 & $\begin{array}{r}-0.084 \\
(7.11)\end{array}$ & $\begin{array}{l}.5 .79 \\
(6.65)\end{array}$ & 27.93 \\
\hline Multan & 24.03 & $\begin{array}{c}-0.079 \\
(4.84)\end{array}$ & $\begin{array}{l}11.44 \\
(9.53)\end{array}$ & 66.29 & 21.46 & $\begin{array}{c}-0.086 \\
(7.39)\end{array}$ & $\begin{array}{r}6.068 \\
(7.07)\end{array}$ & 32.34 \\
\hline Okara & 20.58 & $\begin{array}{c}-0.026 \\
(1.34)\end{array}$ & $\begin{array}{l}10.32 \\
(7.27)\end{array}$ & 71.53 & 18.55 & $\begin{array}{c}-0.042 \\
(2.99)\end{array}$ & $\begin{array}{c}5.12 \\
(4.93)\end{array}$ & 17.92 \\
\hline Peshawar & 28.28 & $\begin{array}{c}-0.166 \\
(4.35)\end{array}$ & $\begin{array}{l}21.06 \\
(7.71)\end{array}$ & 39.33 & 25.38 & $\begin{array}{r}-0.163 \\
(5.69)\end{array}$ & $\begin{array}{l}13.75 \\
(6.52)\end{array}$ & 26.23 \\
\hline Rawalpindi & NA & NA & NA & NA & NA & NA & NA & NA \\
\hline Sahiwal & 23.78 & $\begin{array}{c}-0.062 \\
(3.21)\end{array}$ & $\begin{array}{c}10.19 \\
(7.13)\end{array}$ & 41.34 & 21.23 & $\begin{array}{r}-0.072 \\
(5.14)\end{array}$ & $\begin{array}{c}4.95 \\
(4.84)\end{array}$ & 16.57 \\
\hline Sargodha & 22.98 & $\begin{array}{c}-0.042 \\
(2.43)\end{array}$ & $\begin{array}{l}10.73 \\
(8.36)\end{array}$ & 77.16 & 20.69 & $\begin{array}{r}-0.059 \\
(4.52)\end{array}$ & $\begin{array}{c}5.54 \\
(5.64)\end{array}$ & 19.16 \\
\hline Sialkot & 21.97 & $\begin{array}{c}-0.06 \\
(4.09)\end{array}$ & $\begin{array}{c}10.57 \\
(8.03)\end{array}$ & 54.63 & 20.69 & $\begin{array}{r}-0.053 \\
(4.78)\end{array}$ & $\begin{array}{c}7.52 \\
(4.93)\end{array}$ & 20.71 \\
\hline
\end{tabular}

Sources: Computations are based on price data from [11]. For other data, see Mohammad [9, pp. 267-68].

Notes: (i) *Prices here refer to average monthly wholesale prices received by the farmer. Figures in brackets are $t$-values.

(ii) $\mathrm{NA}=$ Data not available wholesale prices (WP) and retail prices (RP), which could be used to calculate the gross margin of the wholesaler and the retailer taken together. ${ }^{12}$

Accordingly, using wheat and rice prices we estimated gross marketing margins (GM) as follows:

$$
G M=(R P-W P)
$$$$
\text { - } \quad \cdots \quad \ldots
$$

As a percentage of wholesale price,

$$
(R G)=(G M / W P) \times 100
$$

$\cdots$

Such calculations were made for the years from 1955 to 1971 for wheat, and for the 1960 - 1971 period for rice for all the markets mentioned earlier. A summary of these estimates is presented in Table 3. It can be seen from this table that compared with the rates of gross margins for 1955-60 and 1960-66, those for the 1967-71 period are significantly less. The average rate of gross margin in wheat, for example, for all the markets was 7.2 percent for the 1967-71 period, whereas the corresponding rates for $1955-60$ and $1961-66$ are 11.48 percent and 10.74 percent respectively. In the case of rice the average margin for the 1967-71 period was 19.25 percent whereas it was estimated to be 23.04 percent for the $1960-66$ period. The differences among these rates are significant at the 5-percent level.

\section{Storage Margin of the Stock-Keeper}

To test the hypothesis that the farmer's search for a better price over time and space also led to a decline in the margin earned by the private stock-keeper, we estimated both gross and net off-season changes in wholesale price as measures of storage margin. In the absence of the actual data on storage margins in the country, this was one of the most suitable measures one could employ for the purpose. Accordingly we estimated

$$
\begin{aligned}
\text { GOC } & =\frac{\sum_{t=1}^{T}\left(P_{t}-P_{h}\right)}{T} \\
N O C & =\frac{\sum_{t=1}^{T}\left[\left(P_{t}-P_{h}\right)-\left(S c_{t}\right)\right]}{T}
\end{aligned}
$$

\footnotetext{
${ }^{12}$ Gross margin includes both handling charges and the trader's margin.
} 
Table 3

Intertemporal Comparison of Gross Margins (of the Wholesale and the Retailer taken together) in Different Agricultural Markets in Pakistan

\begin{tabular}{|c|c|c|c|c|c|c|}
\hline \multirow[b]{2}{*}{ Markets } & \multicolumn{3}{|c|}{ Wheat } & \multicolumn{3}{|c|}{ Rice (Coarse) } \\
\hline & $\begin{array}{c}1955-56 \\
\text { to } \\
1960-61\end{array}$ & $\begin{array}{c}1961-62 \\
\text { to } \\
1965-66\end{array}$ & $\begin{array}{c}1967-68 \\
\text { to } \\
1970-71\end{array}$ & $\begin{array}{c}1955-56 \\
\text { to } \\
1960-61\end{array}$ & $\begin{array}{c}1961-62 \\
\text { to } \\
1965-66\end{array}$ & $\begin{array}{c}1967-68 \\
\text { to } \\
1970-71\end{array}$ \\
\hline Faisalabad & $13.18^{*}$ & $9.16^{*}$ & 5.48 & NA & $25.52 * *$ & 20.90 \\
\hline Gujranwala & $10.75^{*}$ & $6.93^{* *}$ & 5.05 & NA & $18.85^{* *}$ & 14.27 \\
\hline Hyderabad & $15.75 *$ & $10.23 *$ & 6.88 & NA & $23.61 *$ & 19.34 \\
\hline Karachi & $10.08 * * *$ & $21.52 *$ & 9.82 & NA & $26.52 * * *$ & 24.15 \\
\hline Lahore & 7.08 & $12.62 *$ & 9.81 & NA & $22.45^{* *}$ & 19.78 \\
\hline Multan & $12.94 * *$ & $12.84 * *$ & 11.62 & NA & $23.14 * *$ & 20.03 \\
\hline Okara & NA & NA & NA & NA & NA & NA \\
\hline Peshawar & 6.27 & 7.08 & 7.29 & NA & $24.95 * *$ & 20.43 \\
\hline Rawalpindi & $17.29 *$ & 7.19 & 9.07 & NA & $22.05 * *$ & 19.25 \\
\hline Sahiwal & NA & NA & NA & NA & NA & NA \\
\hline Sargodha & 9.18 & $9.06^{* * *}$ & 7.99 & NA & $20.27 *$ & 15.13 \\
\hline Average & $11.48 * *$ & $10.74 * *$ & 7.02 & NA & $23.04 * *$ & 19.25 \\
\hline
\end{tabular}

Sources: Computations are based on price data from [11]. For other data, see Mohammad $[9$, pp. 267-68].

Notes: (i) The number of stars on any figure indicates the level of significance at which the $1967-71$ average is lower than the averages for previous periods. Thus,

*denotes significant at 1-percent,

**denotes significant at 5 -percent, and

***denotes significant at 10 -percent.

(ii) N.A. = Data not available where

$$
\begin{gathered}
S C \text { (Storage Cost })=(R+I+L+D) \\
R G O C=\left(G O C / P_{h}\right) \times 100 \\
R N O C=\left(N O C / P_{h}\right) \times 100
\end{gathered}
$$$$
\begin{array}{lll}
\ldots & \ldots & \ldots \\
\ldots & \ldots & \ldots \\
\ldots & \ldots & \ldots
\end{array}
$$

GOC and NOC respectively denote 'Gross Off-season Change' and 'Net Off-season Change' in the price of a commodity in any market in a particular year; $P_{t}=$ average wholesale price in the 'off-season months' $(t)$ (namely, August to April for wheat and February to October for rice), $P_{h}$ is average wholesale price in any market in the 'harvesting months' (h) (namely, May to July for wheat and November to January for rice), $R$ is rent of the storage area, $(I)$ is interest on the capital borrowed (or the opportunity cost of the capital invested), $L$ is losses in storage (calculated as one percent of the value of the stored commodity), and $D$ is depreciation of bags and other material used in storage. All the components of the storage costs were calculated on a monthly basis.

A summary of the estimates of RGOC and RNOC so obtained is presented in Table 4. It is clear from these estimates that both RGOC and RNOC went down during the Green Revolution period. The average RGOC is 8.32 percent and the RNOC is -4.57 percent in the case of wheat for the 1967-71 period, whereas the corresponding RGOC figures for the $1955-60$ and 1961-66 periods, respectively, are 16.45 percent and 2.99 percent and for RNOC they are 2.23 percent and 0.54 percent. In the case of rice, the 1967-71 figures are also lower than the $1961-66$ figures. For example, the $1967-71$ RGOC is 11.21 percent and the RNOC is -0.65 percent whereas for $1960-66$ the respective figures are 15.52 percent and 1.68 percent. In most cases, the 1967-71 figures are significantly lower than those for the previous periods at the 5 -percent level or less. Therefore, the hypothesis that the storage margin fell during the Green Revolution period can be accepted.

\section{Checking for Other Confounding Factors}

Regarding the results presented so far, it could be argued that the prices of wheat and rice increased during the 1967-71 period not so much because the market encourged this to happen, but because the government raised floor prices and bought most of the marketable surplus at those prices. To guard against this problem, we calculated coefficients of correlation between floor prices and 'private market prices' in various markets over the period under study to determine the magnitude of the relationship between the two sets of prices. We found that these correlation coefficients ranged between .108 and .141 in the case of wheat prices and between 083 and .221 in the case of rice prices. They were all insignificant even at the 10 percent level, indicating that during the period under study, 'private market prices' were not influenced by the 'floor prices' announced by the government. 
Intertemporal Comparison of Gross and Net Off-season Rise in Average Wholesale Price of Wheat and Rice (Coarse) in Different Agricultural Markets in Pakistan,

1955.56 to $1970-71$

\begin{tabular}{|c|c|c|c|c|c|c|c|c|c|c|c|c|}
\hline \multirow{2}{*}{ Market } & \multicolumn{6}{|c|}{ Gross margin } & \multicolumn{6}{|c|}{ Net margin } \\
\hline & $\begin{array}{l}55-56-1 \\
59-60\end{array}$ & $\begin{array}{l}1960 / 61-\quad 1 \\
1965 / 66\end{array}$ & $\begin{array}{c}1967 / 68- \\
1970 / 71\end{array}$ & $\begin{array}{c}1955 / 56- \\
1959 / 60\end{array}$ & $\begin{array}{c}1960 / 61- \\
1965 / 66\end{array}$ & $\begin{array}{c}1967 / 68- \\
1970 / 71\end{array}$ & $\begin{array}{c}1955 / 56- \\
1959 / 60\end{array}$ & $\begin{array}{c}1960 / 61- \\
1965 / 66\end{array}$ & $\begin{array}{c}1967 / 68- \\
1970 / 71\end{array}$ & $\begin{array}{c}1955 / 56- \\
1959 / 60\end{array}$ & $\begin{array}{c}1960 / 61-1 \\
1965 / 66\end{array}$ & $\begin{array}{c}1967 / 68- \\
1970 / 71\end{array}$ \\
\hline Faisalabad & $20.17 *$ & $13.67 *$ & 8.38 & NA & $13.85^{*}$ & 8.38 & $5.63 *$ & $0.39 *$ & -5.92 & NA & $0.11 *$ & -3.21 \\
\hline Gujranwala & $15.71 *$ & $12.69 * *$ & 9.04 & NA & $13.56 * *$ & 10.64 & $2.09 *$ & $-0.06 * *$ & -4.3 & NA & -0.37 & -1.07 \\
\hline Hyderabad & $15.70^{*}$ & $11.74 * * *$ & 8.96 & NA & $16.39 * *$ & 12.45 & $2.38 *$ & $-1.06^{* *}$ & -3.98 & NA & $2.01 * *$ & -0.78 \\
\hline Karachi & 9.22 & $11.59 * * *$ & 8.29 & NA & 13.95 & 11.80 & -4.17 & $0.91^{* *}$ & -4.00 & NA & $1.15^{*}$ & -0.45 \\
\hline Lahore & $16.38^{*}$ & $13.38 *$ & 8.07 & NA & $17.92 * *$ & 13.50 & $2.34 *$ & $0.41^{*}$ & -4.57 & NA & $3.14 * *$ & 1.24 \\
\hline Multan & $19.24 *$ & $12.18^{* *}$ & 9.44 & NA & $13.73 * *$ & 10.43 & $3.99 *$ & $-0.92 * *$ & -3.68 & NA & $0.31 * *$ & -1.03 \\
\hline Rawalpindi & $14.45^{*}$ & $11.57 * *$ & 8.01 & NA & NA & NA & 0.72 & -2.15 & -5.01 & NA & NA & NA \\
\hline Sahiwal & $19.26 *$ & $12.87^{*}$ & 7.23 & NA & $17.26 * *$ & 13.62 & $3.46^{*}$ & $-1.33 * *$ & -5.09 & NA & $2.59 * *$ & 1.32 \\
\hline Sargodha & $17.20 *$ & $12.01 * *$ & 8.53 & NA & NA & NA & 2.75 & $-1.38 * *$ & -4.06 & NA & NA & NA \\
\hline
\end{tabular}

Table 4 - (Continued)

\begin{tabular}{llllllllllllll}
\hline Sialkot & $17.70^{*}$ & $12.30 * *$ & 7.93 & NA & $18.27 *$ & 12.22 & $5.06 *$ & 1.16 & -5.11 & NA & $5.15^{*}$ & -0.67 \\
Average & $16.45^{*}$ & $12.29 * *$ & 8.32 & NA & $15.52 * *$ & 11.21 & $2.23 *$ & $-0.54 * *$ & -4.57 & NA & $1.68 * *$ & -0.65 \\
\hline
\end{tabular}

Sources: Computations are based on price data from [11]. For other data see Mohammad [9, pp. 267-68].

Notes: (i) The number of stars indicates the level of significance at which the 1967-71 value is lower than the values for previous periods. Thus, *denotes significant at 1-percent,

$* *$ denotes significant at 5 -percent, and

***denotes significant at 10 -percent.

(ii) $\mathrm{NA}=$ Data not available 
One of the possible reasons for this insignificant relationship between the two sets of prices is the small proportion of marketable surplus which the government used to buy up to 1968-69. For example, in 1964-65 the government procured only 430 tons of wheat which was 0.0095 percent of the total production in that year. Similarly in 1967-68 the government procured 4554 tons which was only 0.072 percent of the year's total wheat production. Only in 1969-70 did the government procure large quantities of wheat, but that, too, was through private marketing system, which still allowed these markets to function without being directly influenced by changes in the procurement schemes. As regards (coarse) rice, the government procured practically little of it until 1970-71 [11].

It may, therefore, be safe to state that procurement schemes of the government had little effect on the above- mentioned shift in the prices of wheat and rice, received by the farmer during the Green Revolution period.

\section{CONCLUSIONS}

Our results in this paper about farm prices and the trader's margins do not support the popular preception of the private agricultural markets in Pakistan that they are incapable of accommodating increases in marketable surplus with adequate reward to the farmer. It appears that, by allowing better prices to the farmer, agricultural markets in Pakistan rather facilitated the adoption of high-yielding new varieties in the Sixties. This is a sign of their good health, which must be kept in mind while devising any policy package to further improve their performance.

\section{REFERENCES}

1. Bilas, Richard S. Microeconomic Theory. (Second Edition.) New York: McGraw-Hill Book Company. 1971. pp. 173-196, 267-69, and 305-25.

2. Griffin, Keith. The Political Economy of Agrarian Change. Cambridge, Mass.: Harvard University Press. 1972.

3. Harris, Barbara. "There is Method in My Madness: Or Is It Vice Versa? Measuring Agricultural Market Performance". Food Research Institute Studies. Vol. XVII, No. 2. 1979.

4. Jones, William O. "Regional Analysis and Agricultural Marketing Research in Tropical Africa: Concepts and Experience". Food Research Institute Studies. Vol. 13. No. 1. 1974. pp. 3-28.

5. Jones, William O. "The Structure of Staple Food Marketing in Nigeria as Revealed by Price Analysis". Food Research Institute Studies. Vol. 8, No. 2. 1968. pp. $95-123$.

6. Khan, M. H. The Economics of Green Revolution. New York, Washington and London: Praeger Publishers. 1979.
7. Lele, U. J. Foodgrain Marketing in India: Private Performance and Public Policy. Ithaca: Cornell University Press. 1971.

8. Mohammad, Faiz. "Pricing Efficiency in Agricultural Markets in Pakistan". Islamabad: Pakistan Institute of Development Economics. 1977. (Research Report No. 106)

9. Mohammad, Faiz. "An Analysis of Structure and Performance of Agricultural Markets in Pakistan". Unpublished Ph.D. Dissertation, Simon Fraser University, British Columbia, Canada. January 1983.

10. Pakistan. Ministry of Food and Agriculture. Agricultural Statistics of Pakistan Islamabad. (For 1970, 1975 and 1980)

11. Pakistan. Ministry of Food and Agriculture. Agricultural Marketing Adviser. Marketing and Prices. Karachi. (Various years)

12. Pitchard, N. T. "Framework for Analysis of Agricultural Marekting System in Developing Countires". Agricultural Economics Research. Vol. 21, No. 3 July 1969. pp. 78-85.

13. Qureshi, S. K. "The Performance of Village Markets for Agricultural Produce: A Case Study of Pakistan”. Pakistan Development Review. Autumn 1974. pp. 280-307.

14. Smith, E. D. "Agricultural Marketing Research for Less Developed Areas". American Journal of Agricultural Economics. November 1972. pp. 666-70. 